\title{
ANALYSIS AND EVALUATION OF THE MEASUREMENT SYSTEM BASED ON KAMA ORIFICES FOR MEASURING THE FLOW OF SEWAGE IN THE LIGHT OF THE WATER LAW REQUIREMENTS
}

\author{
Andrzej Mączałowski ${ }^{凶}$ \\ Department of Geoengineering and Water Management, Cracow University of Technology, ul. Warszawska 24, 31-155 Kraków
}

\begin{abstract}
Aim of the study

Analysis and evaluation of the operation of KAMA measuring systems in relation to the currently used other measuring devices and techniques to control sewage discharge in accordance with the requirements of the new WATER LAW.
\end{abstract}

\begin{abstract}
Material and methods
Measurement data of controlled measuring systems KAMA R1500 and KAMA 1000 and characteristics of measuring devices from other producers.

\section{Results and conclusions}

Control measurements of KAMA measuring systems in a circular collector and in a rectangular open channel are presented as examples of the most common variants of geometry of drop points. The obtained accuracy of measurement of the flow rate of KAMA orifices were referred to other currently used techniques and measuring devices, indicating the most important reasons for lower than one would expect accuracy in this range.

The awareness of the equivalence of the used devices and measurement techniques in constant monitoring of the flow rate of discharged wastewater may be helpful in a rational construction of the control and measurement system.
\end{abstract}

Keywords: water law, waste water discharge, flow measurement, measuring devices

\section{INTRODUCTION}

On 1st of January 2018, a new water law entered into force (the Act of 20th of July 2017), which introduces a number of new regulations. Among them is an obligation to control the quantity and temperature of discharged sewage. In division II "Use of waters", in section 1 "Use of waters and water services" art. 36 states as follows:

1. An entity using water services that extracts surface water or groundwater as part of water services is obliged to use measuring instruments that allow measuring the quantity of water taken.

2. An entity using water services that introduces sewage into waters or into the ground as part of water services is obliged to use measuring instruments or measuring systems that allow to measure the quantity and temperature of discharged sewage, if introduces sewage into waters or into the ground in an average daily quantity above $0.01 \mathrm{~m}^{3} \cdot \mathrm{s}^{-1}$.

3. Polish waters provide the entities referred to in para. 1 and 2, at their own expense, with measuring

凶e-mail: andrzej.maczalowski@iigw.pk.edu.pl 
instruments enabling measurement of the quantity of water taken or measurement of the quantity and temperature of discharged sewage.

4. Entities referred to in para. 1 and 2, with the consent of Polish Waters, can equip themselves with measuring instruments enabling measurement of the quantity of water taken or measurement of the quantity and temperature of discharged sewage.

5. If the results of water management control indicate that the land owners, who are entitled to regular use of water, referred to in art. 33:

1) intake groundwater or surface water in a quantity annually exceeding $5 \mathrm{~m}^{3}$ per day,

2) discharge sewage into waters or into the ground in a quantity exceeding in total $5 \mathrm{~m}^{3}$ per day

Polish Waters may, at their own expense, equip those landowners with measuring instruments enabling measurement of the quantity of water taken or sewage discharged.

The quoted art. 36 indicates that the obligation to control the quantity of discharged sewage regards, for example, sewage treatment plants serving over 5.500 inhabitants (assuming that on average every inhabitant of the city produces 155 litres of sewage per day) (Pawelek et al., 2006). Taking into account real cases, it should be noted that the new obligation will apply to the vast majority of sewage treatment plants, and according to data provided by the Central Statistical Office in 2017, there were 4184 of these in Poland. On possible operating conditions of treatment plants and quantities of received sewage one can find in Młyński et al. (2017), Bugajski et al. (2016) or Bugajski (2009).

Reading in the intention of the new water law, it also allows to control e.g. large discharges of stormwater from a combined sewerage system or precitipation from rainwater sewers, which - although they do not operate continuously - can under certain conditions (e.g., the occurrence of cloudbursts) lead to the receiver during the day, over $864 \mathrm{~m}^{3}$ of sewage (i.e. $\left.0.01 \mathrm{~m}^{3} \cdot \mathrm{s}^{-1} \cdot 24 \cdot 60 \cdot 60 \mathrm{~s}\right)$.

Paragraph 4. is very important. Considering its content, it should be understood that this provision carries a huge financial burden. As the obligation to control the volume of sewage discharge takes effect from 31 December 2020, at the moment as the Central Office of Measures states (Główny Urząd Miar), actions to cover the measuring instruments listed in the Water Law Act with legal metrological control are underway.

Aim of this paper is to review the applied measuring techniques and devices, provide own examples of their application and indicate possible difficulties in their implementation in relation to the new water law.

\section{TYPES OF MEASUREMENT TECHNIQUES}

In general, flow measurement methods can be divided into direct and indirect techniques. It is commonly known that the most accurate is direct measurement (volumetric method), but due to technical restraints it is very rarely possible to perform this measurement. This method can be only used in research laboratories that determine hydraulic features of measuring devices and in installations or channels with very low flow rates. This means that the only available option in engineering practice for determining flow rate are indirect measurements. Among them are distinguished: measuring channels, measuring spillways, measuring orifices, and techniques using electromagnetic, ultrasonic, radar or laser flow rate meters.

Applied measuring techniques were examined by, among others: Michalski et al. (2006), Wójcik et al. (2014) and Absalon et al. (2015). Dynamic development of technology needs to be appreciated as designed devices are faster and more accurate than ever. The basics of taking measurements, however, are unchangeable. In the case of classical methods (see: Fig. 1), flow rate is determined by measuring the level (or ordinate) of water surface in a channel. The thickness of water layer on spillway $\mathrm{H}$ is obtained by subtracting measuring spillway crown ordinate from obtained water surface ordinate. Only with this information, based on spillway characteristics, makes it possible to determine
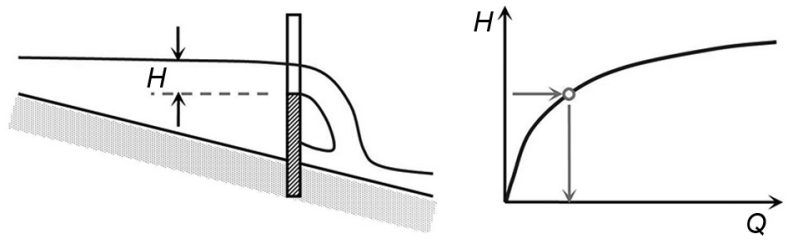

Fig. 1. The use of measuring weir to determine flow rate in the channel 
Q flow rate value. This solution (triangular spillway and ultrasonic probe for measuring water table level) was used by Grzegorz Kaczor (2011).

As for newer techniques, flow rate, speaking simply, is determined on the basis of flow velocity measurement at selected points of measurement plots (depending on the methodology) or continuously in measuring cells covering the entire surface of measurement cross-section. The obtained image of ve- locity distribution in measurement cross-section (see: Fig. 2) enables determining the areas, in which velocity is the same. The sum of products of these fields and their velocity is equal to flow rate value.

Devices available on the market are equipped with calculation modules, which perform operations described above on regular basis and automatically give flow rate value in addition to monitoring of measured values.

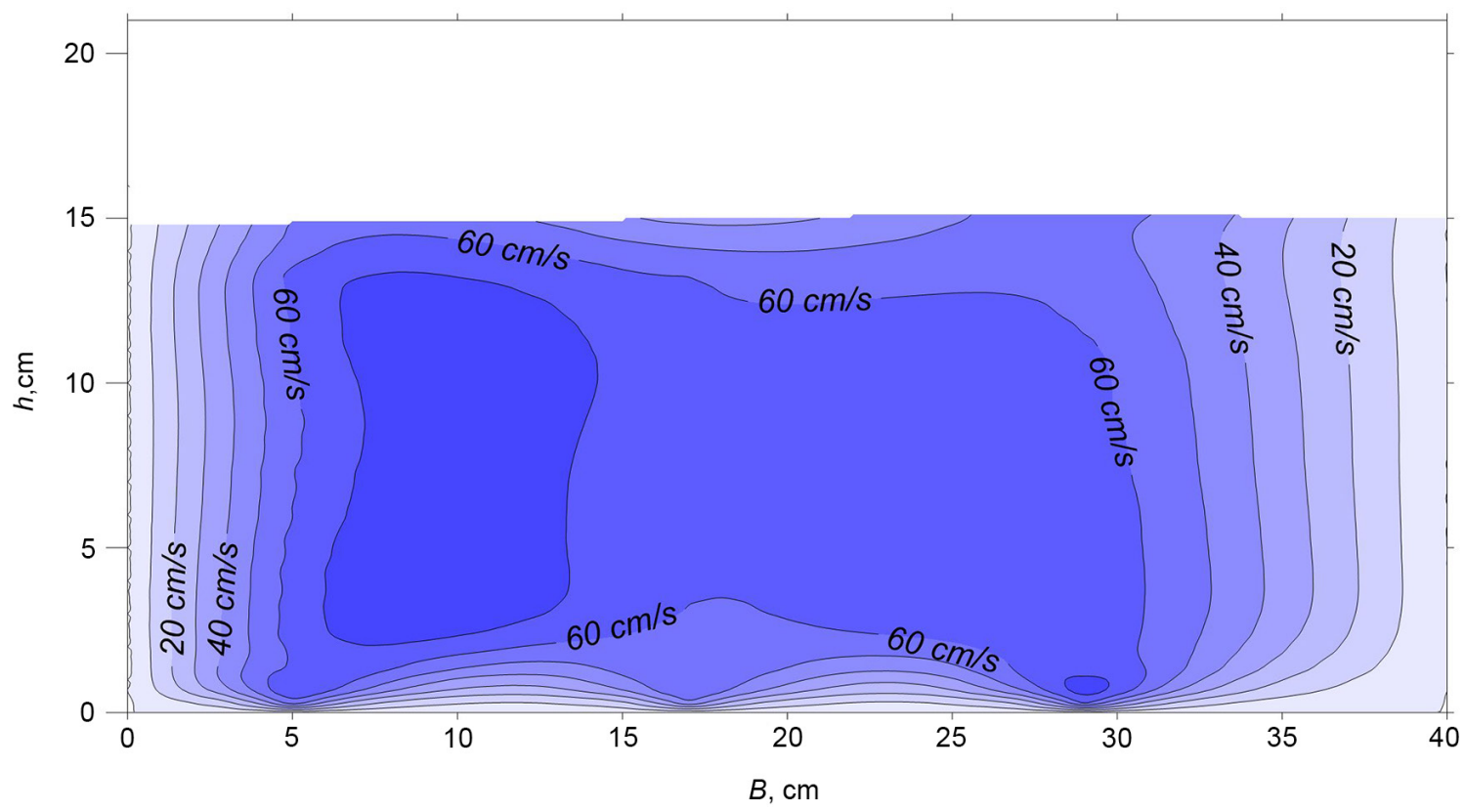

Fig. 2. An example of flow velocity distribution in a rectangular channel

\section{MATERIALS AND METHODS}

Basic flow velocity measuring device for described here control measurements was the traditional $\mathrm{He}-\mathrm{Ga} 1$ hydrometric mill with a $50 \mathrm{~mm}$ diameter impeller and velocity measurement range from $0.04-2.5 \mathrm{~m} \cdot \mathrm{s}^{-1}$. It was employed on account of dimensions of controlled measurement cross-sections and limited surface at the measurement site. Based on point measurements made for each case, a spatial flow velocity distribution was developed using the most common "kriging" method with a linear variogram (creating a regular grid of $z=\mathrm{f}(\mathrm{x}, \mathrm{y})$ function values with a finite number of XYZ points) using the Surfer 10 program from Golden Software.
Due to a number of devices needed to control sewage discharges this paper studies one of the most viable measuring devices, i.e. measuring orifices. Since the points of discharge of treated wastewater flowing out of a sewage treatment plant to a receiver most often have a shape of large circular collectors or rectangular open channel, popular in Poland orifices KAMA R1500 and KAMA 1000 (see: Fig. 3) were chosen for the analysis.

Orifices themselves do not measure velocity field, but only based on exact measurement of water surface (wastewater) ordinate from orifice hydraulic features (rating curve) that an actual flow rate is read (analogically to measuring spillways). This is a classical solu- 


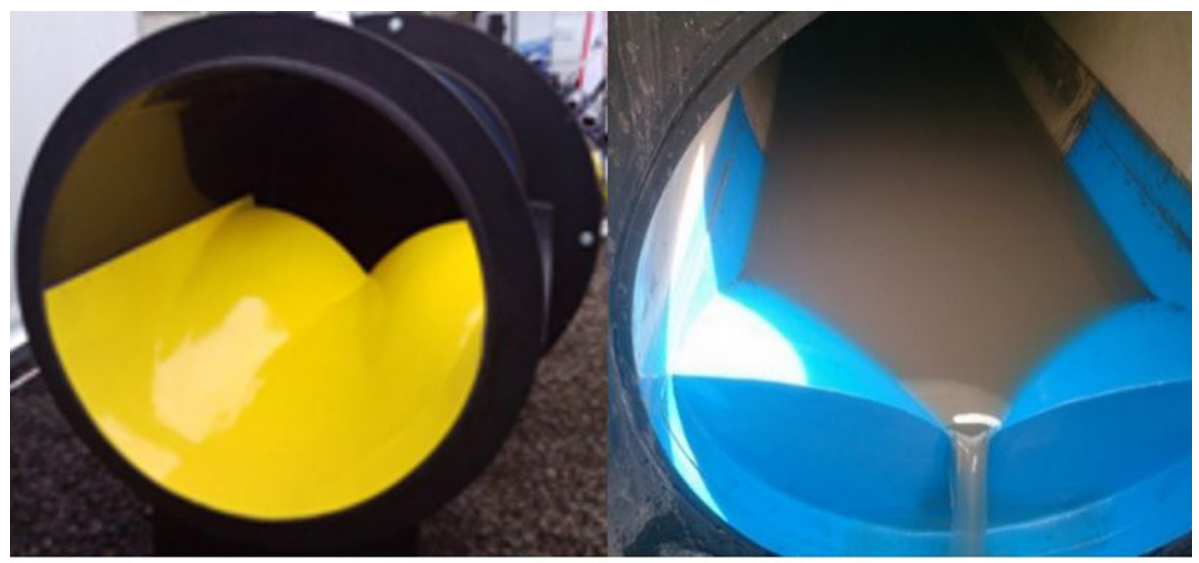

a) KAMAR orfice (for circular collectors)

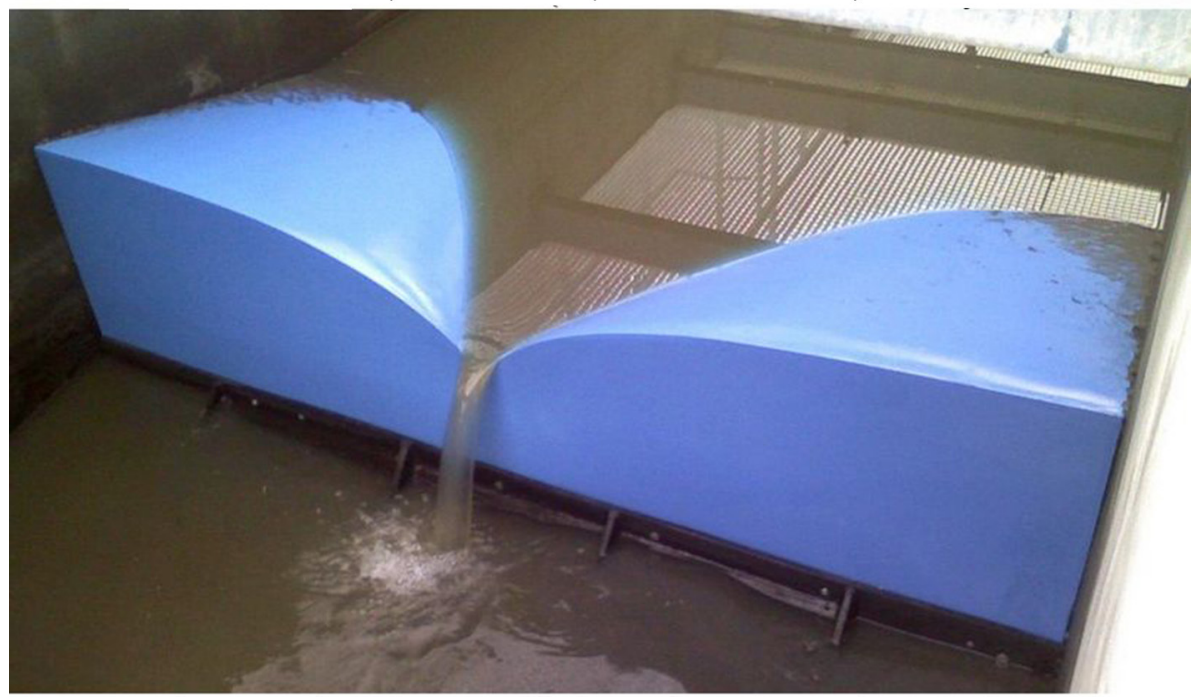

b) KAMA orifice (for rectangular channels)

Fig 3. KAMA orifices

tion that enforces a laminar system of streams at orifice length, concentration of sewage stream in a central part and ensures transport of contaminants through an orifice with an original (patented) orifice shape (based on manufacturer's experience achieved during constructing aircraft). The producer of KAMA orifices additionally states that it is possible to segment the construction, the orifice can be mounted even in hard-to-reach places (accessible only through a manhole) and orifice construction itself is resistant to friction due to applied materials and can also be used with sewage containing various types of pollution or sand.

The first of the presented devices is the KAMA $\mathrm{R} 1500$ orifice with a measurement range from 0 to
$6000 \mathrm{~m}^{3} \cdot \mathrm{h}^{-1}$, which together with additional equipment (SM-03 measuring station and ultrasonic level sensor) were installed in a discharge collector behind the sewage treatment plant in Bielsko-Biala. The SM03 station is a very important element of the measurement system, because it receives a signal from a sensor measuring the level of water surface over an orifice's crown, converts it to flow rate value and then saves and shares it online with an entire history of the last 370 days. The sewage treatment plant in Bielsko-Biała is cleaning both mechanically and biologically annually approx. 12 million $\mathrm{m}^{3}$ of municipal and industrial wastewater. According to the received water law permit, an average daily discharge 
is $90.000 \mathrm{~m}^{3} \cdot \mathrm{d}^{-1}$, the maximum daily discharges under intense rainfall conditions is $124.000 \mathrm{~m}^{3} \cdot \mathrm{d}^{-1}$ and the maximum hourly discharge for such conditions is $5.200 \mathrm{~m}^{3} \cdot \mathrm{h}^{-1}$. According to Stanisław Lach $(2016)$, this plant in the analysed period worked under hydraulic underload and the average value of daily sewage inflow to the sewage treatment plant was $66.05 \%$ of projected rate.

In another example, the measuring system equipped with a KAMA 1000 orifice (with a measuring range from 0 to $2000 \mathrm{~m}^{3} \cdot \mathrm{h}^{-1}$ ) was installed in a rectangular open channel for wastewater from a mechanical-biological agglomeration treatment plant in Otwock (receiving municipal and industrial wastewater from the municipalities of Otwock, Karczew, Józefów and Celestynów). According to the water permit $Q_{\max h}=$ $1340 \mathrm{~m}^{3} \cdot \mathrm{h}^{-1}, Q_{\text {avg } d}=15500 \mathrm{~m}^{3} \cdot \mathrm{d}^{-1}$ and $Q_{\max d}=$ $24000 \mathrm{~m}^{3} \cdot \mathrm{d}^{-1}$.

The control measurements in Otwock were made immediately after rapid precipitation over the town, resulting in almost the maximum admissible discharge of wastewater from the sewage treatment plant to a backwater of the Jagodzianka River, located in front of the Vistula River embankment.

\section{MEASUREMENT RESULTS}

Fig. 4 presents the results of control measurements from a measurement system of the Kama R1500. The red markers indicate the location of measurement points and the rates of measured flow velocity. Velocity field distribution was determined (see: Fig. 5) on the basis of the studied flow velocity measurement points (see: Fig. 4) and the average filling of measuring chamber. It was necessary to calculate flow intensity rate $Q_{a v r}=0.514 \mathrm{~m}^{3} \cdot \mathrm{s}^{-1}$. The time required for pointbased velocity measurements in the collector was 22 minutes. From the same period, indications of the KAMA R1500 measuring system have been recorded, as shown in Table 1.

For the data presented in Tab. 1, an averaged value of flow rate was determined $Q_{a v r}=1892.636 \mathrm{~m}^{3} \cdot \mathrm{h}^{-1}=$ $0.526 \mathrm{~m}^{3} \cdot \mathrm{s}^{-1}$ and an average filling above the crown of an orifice $=413.82 \mathrm{~mm}$. Relative error for average values of flow rates was $\pm 2.27 \%$. Taking into account the fact that during control measurements the conditions of flow in the collector were not completely sta- ble and there were slight shifts in flow rate (except for readings at 11:58 and 11:59 AM, when a sudden significant drop in flow rate value occurred) registered error was considered acceptable and the measurement system of KAMA R1500 orifice reliable.

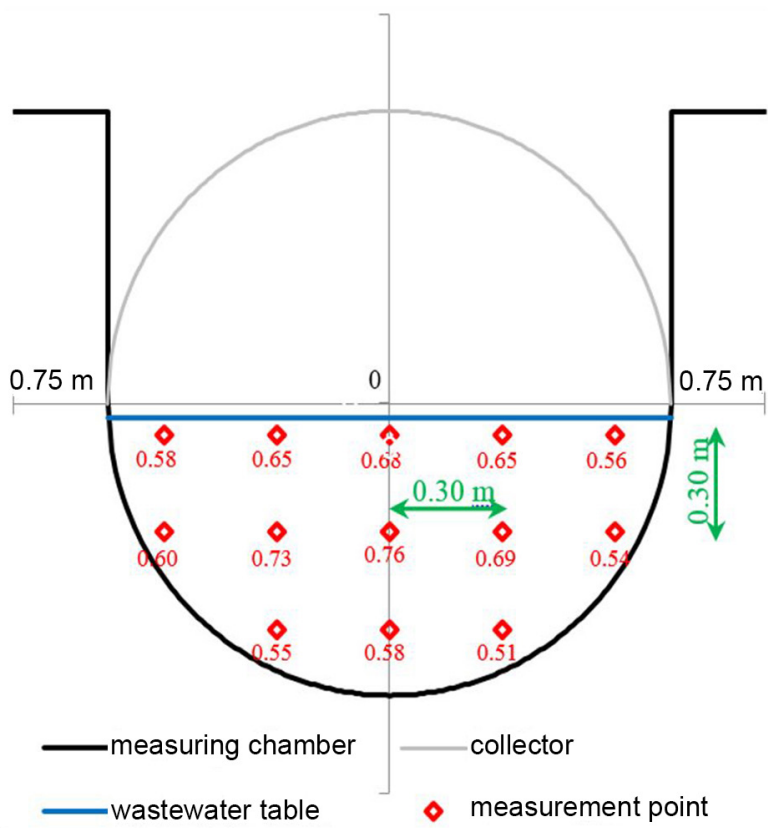

Fig 4. The results of the longitudinal velocity $\left[\mathrm{m} \cdot \mathrm{s}^{-1}\right]$ in the collector $1500 \mathrm{~mm}$

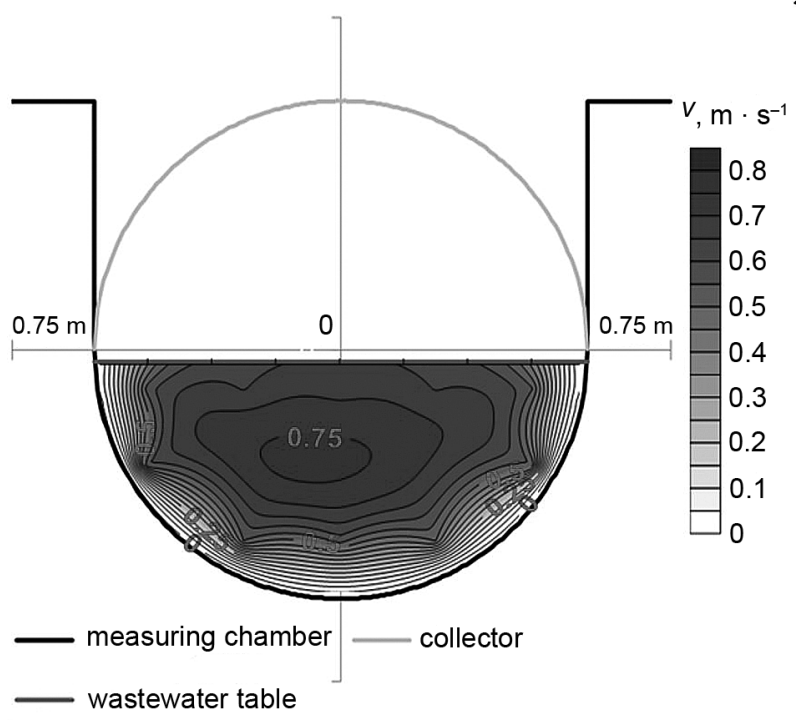

Fig. 5. Longitudinal velocity field in the collector $1500 \mathrm{~mm}$ 
Table 1. Results of the KAMA R1500 measurement system from the time of control measurements

\begin{tabular}{|c|c|c|c|c|}
\hline L.p. & $\begin{array}{l}\text { Q read out } \\
{\left[\mathrm{m}^{3} \cdot \mathrm{h}^{-1}\right]}\end{array}$ & $\begin{array}{l}\text { H over } \\
\text { orifice } \\
{[\mathrm{m}]}\end{array}$ & $\begin{array}{c}\text { Chamber } \\
\text { filling } \\
{[\mathrm{m}]}\end{array}$ & $\begin{array}{c}\text { Time of } \\
\text { measurement } \\
{[\text { h:min }]}\end{array}$ \\
\hline 1 & 1921 & 0.413 & 0.713 & $11: 56$ \\
\hline 2 & 1864 & 0.402 & 0.702 & $11: 57$ \\
\hline 3 & 1459 & 0.390 & 0.690 & $11: 58$ \\
\hline 4 & 1459 & 0.390 & 0.690 & $11: 59$ \\
\hline 5 & 1859 & 0.400 & 0.700 & $12: 00$ \\
\hline 6 & 1864 & 0.401 & 0.701 & $12: 01$ \\
\hline 7 & 1888 & 0.406 & 0.706 & $12: 02$ \\
\hline 8 & 1911 & 0.411 & 0.711 & $12: 03$ \\
\hline 9 & 1902 & 0.409 & 0.709 & $12: 04$ \\
\hline 10 & 1911 & 0.411 & 0.711 & 12:05 \\
\hline 11 & 1902 & 0.409 & 0.709 & $12: 06$ \\
\hline 12 & 1916 & 0.412 & 0.712 & $12: 07$ \\
\hline 13 & 1930 & 0.415 & 0.715 & $12: 08$ \\
\hline 14 & 1944 & 0.418 & 0.718 & $12: 09$ \\
\hline 15 & 1921 & 0.413 & 0.713 & $12: 10$ \\
\hline 16 & 1987 & 0.427 & 0.727 & $12: 11$ \\
\hline 17 & 1987 & 0.427 & 0.727 & $12: 12$ \\
\hline 18 & 1992 & 0.428 & 0.728 & $12: 13$ \\
\hline 19 & 2001 & 0.430 & 0.730 & $12: 14$ \\
\hline 20 & 2011 & 0.432 & 0.732 & $12: 15$ \\
\hline 21 & 2011 & 0.432 & 0.732 & $12: 16$ \\
\hline 22 & 1998 & 0.428 & 0.728 & $12: 17$ \\
\hline
\end{tabular}

As before, Fig. 6 presents the location of measurement points and longitudinal velocity rates in flow field of discharge channel of treatment plant in Otwock, whereas Fig. 7 provides an image of velocity field in the channel. On the basis of measurements of flow velocities shown in Fig. 7 and an average filling of outflow channel, an average flow rate value was determined $Q_{a v r}=0.4105 \mathrm{~m}^{3} \cdot \mathrm{s}^{-1}=1478 \mathrm{~m}^{3} \cdot \mathrm{h}^{-1}$.

Table 2 presents results of the KAMA 1000 measurement system from the period of performing control measurements. Initial analysis of the obtained

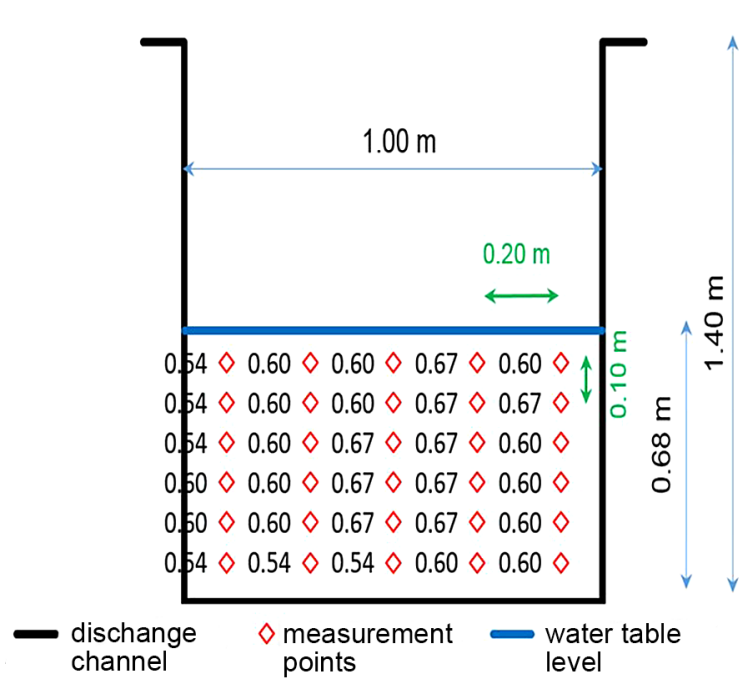

Fig. 6. The results of the longitudinal velocity in the channel $\mathrm{b}=1000 \mathrm{~mm}$

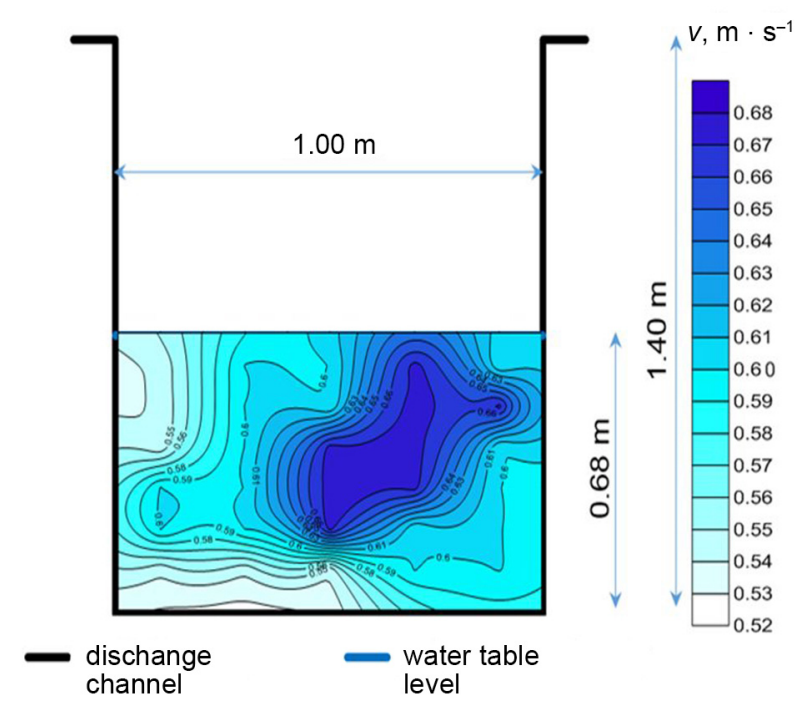

Fig. 7. Longitudinal velocity field in the channel $b=1000 \mathrm{~mm}$

results showed a need to calibrate the measurement system (new determination for levels of the orifice's crown in hydraulic properties). After these, the latest flow rate values were taken into account.

Based on the adjusted data, an average flow rate value in the discharge channel was set to $Q_{a v r}=$ $1420.85 \mathrm{~m}^{3} \cdot \mathrm{h}^{-1}$ and an average filling above the crown of orifice $\mathrm{h}=573.1 \mathrm{~mm}$. Relative error for 
Table 2. Results of the KAMA 1000 measurement system from the time of control measurements

\begin{tabular}{|c|c|c|c|c|}
\hline L.p. & $\begin{array}{c}\text { H over } \\
\text { orifice } \\
{[\mathrm{m}]}\end{array}$ & $\begin{array}{c}\text { Q read } \\
\text { out } \\
{\left[\mathrm{m}^{3} \cdot \mathrm{h}^{-1}\right]}\end{array}$ & $\begin{array}{c}\text { Q after } \\
\text { calibration } \\
{\left[\mathrm{m}^{3} \cdot \mathrm{h}^{-1}\right]}\end{array}$ & $\begin{array}{c}\text { Time of } \\
\text { measurement } \\
{[\text { h:min }]}\end{array}$ \\
\hline 1 & 0.567 & 1140 & 1403 & $11: 25$ \\
\hline 2 & 0.567 & 1140 & 1403 & $11: 26$ \\
\hline 3 & 0.575 & 1162 & 1425 & $11: 27$ \\
\hline 4 & 0.566 & 1149 & 1412 & $11: 28$ \\
\hline 5 & 0.570 & 1155 & 1418 & $11: 29$ \\
\hline 6 & 0.570 & 1155 & 1418 & $11: 30$ \\
\hline 7 & 0.566 & 1149 & 1412 & $11: 31$ \\
\hline 8 & 0.575 & 1162 & 1425 & $11: 32$ \\
\hline 9 & 0.560 & 1140 & 1403 & $11: 33$ \\
\hline 10 & 0.570 & 1155 & 1418 & $11: 34$ \\
\hline 11 & 0.580 & 1170 & 1433 & $11: 50$ \\
\hline 12 & 0.576 & 1161 & 1424 & $11: 51$ \\
\hline 13 & 0.575 & 1162 & 1425 & $11: 52$ \\
\hline 14 & 0.576 & 1161 & 1424 & $11: 53$ \\
\hline 15 & 0.577 & 1164 & 1427 & $11: 54$ \\
\hline 16 & 0.580 & 1170 & 1433 & $11: 55$ \\
\hline 17 & 0.576 & 1161 & 1424 & $11: 56$ \\
\hline 18 & 0.578 & 1164 & 1427 & $11: 57$ \\
\hline 19 & 0.588 & 1182 & 1445 & $11: 58$ \\
\hline 20 & 0.570 & 1155 & 1418 & $11: 59$ \\
\hline
\end{tabular}

average values of flow rates was $\pm 3.87 \%$. Despite a slightly higher value, this error was considered acceptable due to the unusual working conditions of the sewage treatment plant (operating at the maximum sewage discharge).

In these dynamic discharge conditions, further additional control measurements were performed. In another cross-section, point velocity values were also measured, allowing to determine flow field. Fig. 8 shows a comparison of the obtained flow velocity fields. Significant differences in received images indicate flow dynamics in discharge channel, however, the relative error for obtained flow rate values was only $\pm 0.13 \%$, which proves the calculation method to be correct.

It is worth noting that if only the average velocity value for each cross-section was calculated based on point measurements, the error for such a simplified method of calculating the flow rate (without taking into account spatial velocity distribution in flow field) would be $\pm 7.12 \%$. This is a very important experience confirming that the more accurate the measurement result of flow rate we get, the more precisely we image the flow field.

\section{DISCUSSION}

Bearing in mind the costly task of building a control-measurement system for wastewater discharge in accordance with the new water law, it is necessary to consider different available measurement techniques
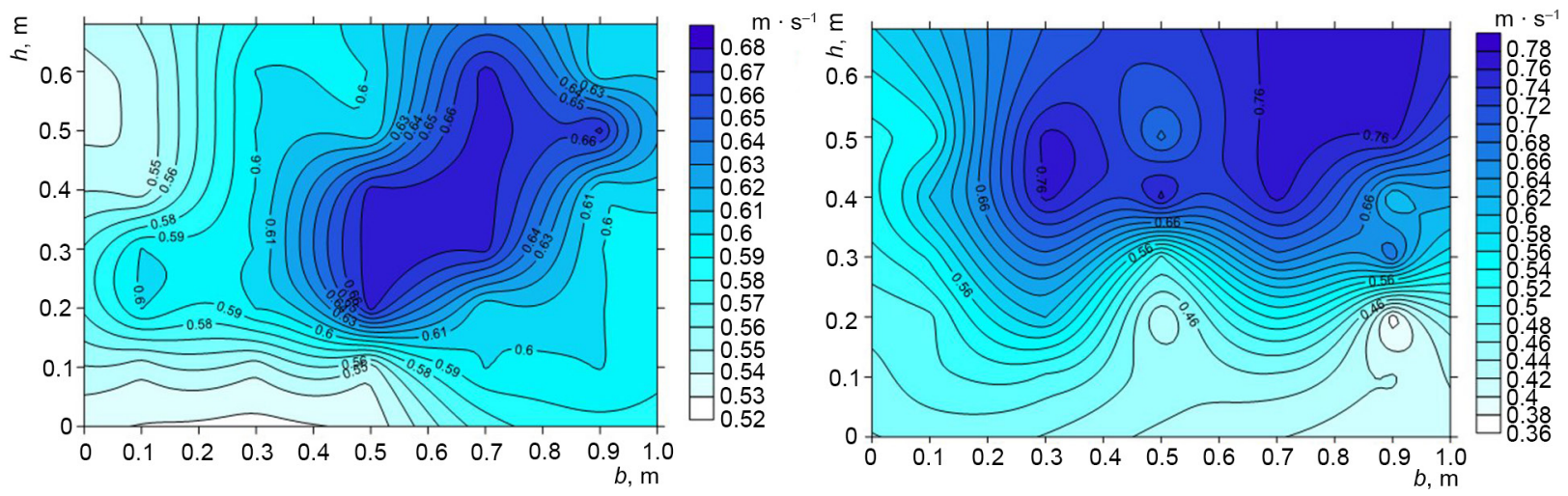

Fig. 8. Comparison of velocity fields for control measurements located in the outflow channel upstream the KAMA 1000 orifice 
that ensure constant measuring, calculating flow rate, recording of results with an assumed time step (e.g. every minute), archiving measurements (e.g. from last year) and enabling remote access to the measurement base.

The described system is one of possible examples. The presented differences between values coming from control measurements and from measurement systems, in which KAMA orifices were used, are within a permissible range. This is confirmed by Wójcik and Wdowikowski (2014).

Among other currently available devices are, for example, ultrasound SonTek-IQ Series (with a range of $\pm 5 \mathrm{~m} \cdot \mathrm{s}^{-1}$ and accuracy $\pm 1 \%$ of the measured value, $0.005 \mathrm{~m} \cdot \mathrm{s}^{-1}$ ) or NivuFlow with a NIS sensor (with a range of $\pm 15 \mathrm{~m} \cdot \mathrm{s}^{-1}$ and accuracy $\pm 0.1 \%$ of the measured value). Both these meters are located at the bottom of a channel or a collector. In spite of evidently higher accuracy of velocity meters themselves, the total error in determining flow rate can be much greater. For such type of devices, it was assumed that the measured vertical velocity distribution over the sensor is a sufficient representation of velocity distribution in flow field. As shown in Fig. 8, this will not always be true. Therefore, it is not surprising that for wide discharge channels it is proposed to increase the number of sensors at the bottom (see: Fig. 9). This certainly improves an image of velocity distribution in flow field, but it does not completely eliminate effects of applied simplification.

However, the difficulty with this type of meter is its inability to measure at low levels of channel filling. SonTek reports that the minimum required filling is $0.05 \mathrm{~m}$. This small value is obviously compensated in a procedure for determining $\mathrm{Q}$ for higher states. Nonetheless, one can imagine a situation that a channel is filled below the required minimum for a longer period. Then, for example, a rectangular channel with a bed width of $1 \mathrm{~m}$, bed drop $1 \%$ and coefficient roughness $n=0.013$, flow rate $Q$ can reach a value of over $1.1 \mathrm{dm}^{3} \cdot \mathrm{s}^{-1}$. Lack of registering even such a small outflow, e.g. in a monthly balance sheet, may lead to significant divergence between real and measured values. In addition, Michalski et al. (2006) indicate that with ultrasonic meters the source of errors will be due to temperature gradients or a degree of salinity along the course of a measuring beam.

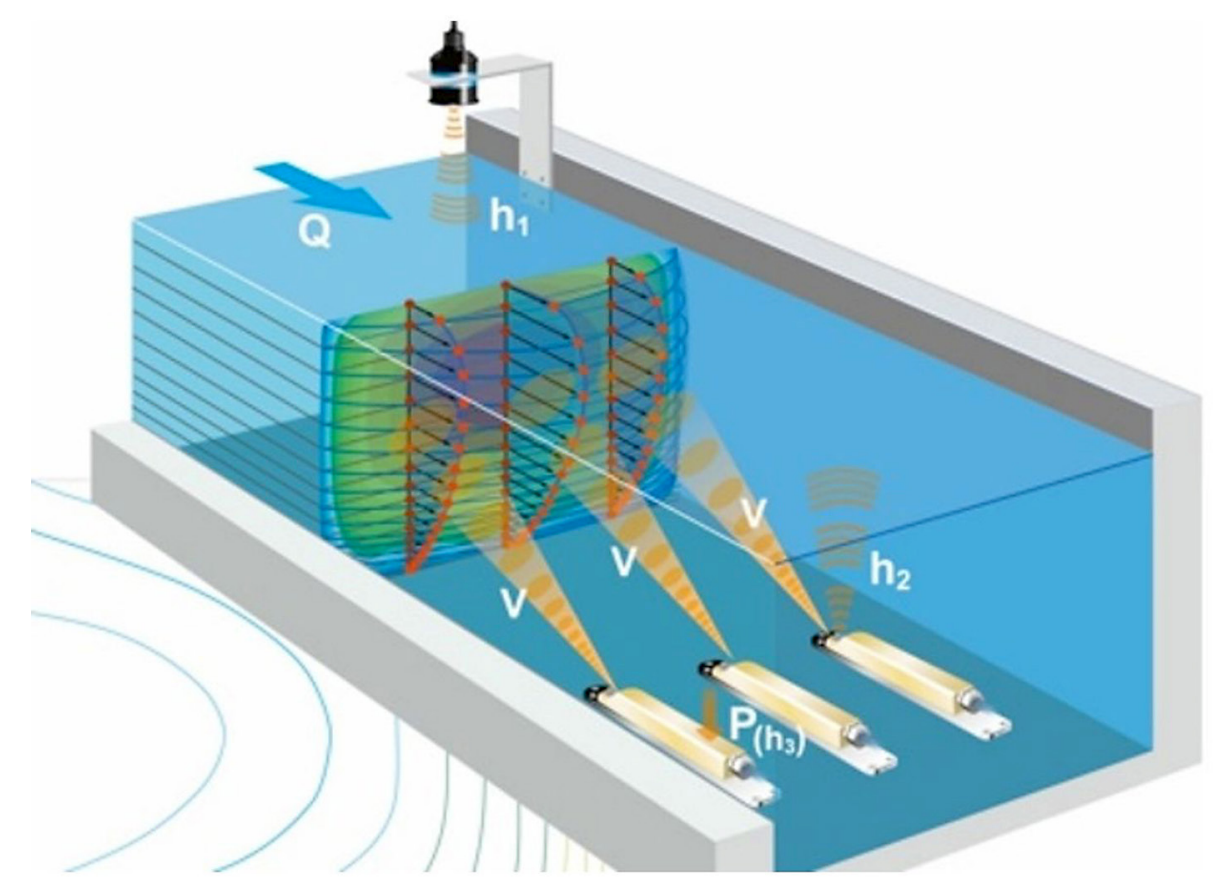

Fig. 9. Expanded measuring system 
It is also possible to place sensors in side walls of a channel. Such a measurement system was described by Abgottspon et al. (2016). Even this arrangement of very accurate sensors will also not allow measuring velocity in entire flow field, but only in selected layers at the levels, where sensors are installed.

The latest measuring devices are radar or laser meters. The former measure surface velocity, the latter can measure velocity even below water table level. Technical data of the Laser Flow meter from TELEDYNE ISCO (see: Fig. 10) shows that despite the accuracy of velocity measurement of $\pm 0.5 \%$ of the measured value $\left(0.03 \mathrm{~m} \cdot \mathrm{s}^{-1}\right)$, the accuracy of flow rate is only as low as $\pm 5 \%$ of the measured value. Tenfold decrease in accuracy is caused by the fact that in real measurements an image of velocity field is not as ideal as in Fig. 10

The mentioned difficulties will not occur when using a tared orifice with an accurate measurement of water (wastewater) surface level.

\section{SUMMARY}

The discussion put forward the most important difficulties that can occur during constant measurements of wastewater flow rate from a sewage treatment plant. Summing up the conducted control measurements of measuring systems using KAMA orifices and comparing their accuracy to other types of currently available measuring devices that can be used in systems controlling wastewater discharge from sewage treatment plants, it should be noted that it is difficult to indicate a clear leader, whose devices are evidently more accurate than others. It turns out that even very high precision of used velocity meters (ultrasonic, radar or laser) is not a guarantee of the highest accuracy of flow rates. Simplifications adopted in a schematization of velocity distribution in flow field are the main reason for this. In such situation, it is necessary to consider the price of available devices, when designing a control-measurement system. Without going into details of the offers of individual suppliers, it can be generally stated that the presented KAMA orifices are the cheapest, whereas ultrasonic meters are at least twice (or three times) more expensive, and radar or laser meters may be even five times more expensive. It is hardly surprising, therefore, that the Kama orifices in recent years have gained recognition of many customers. According to the producer, several hundred such measuring systems were installed (for financial settlements) and even the equipment of competing suppliers was replaced. These orifices have proved themselves well both in measurement of purified and raw sewage (even carrying significant amounts of pollutants).
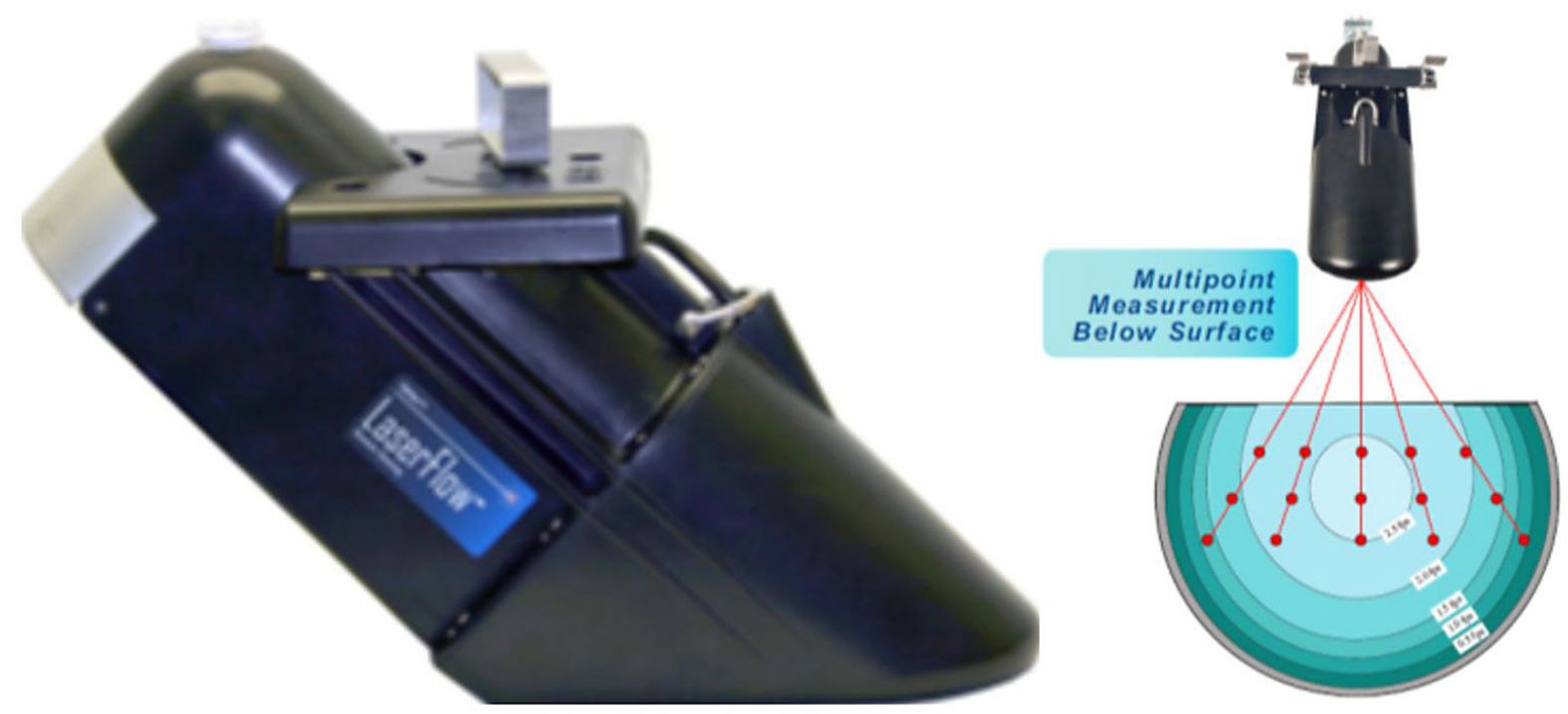

Fig. 10. Laser flow meter TELEDYNE ISCO 
The above-mentioned insight into the field of constant measurements of wastewater discharge can be helpful in rational construction of a control-measurement system in accordance with the conditions set out in the new water law.

\section{REFERENCES}

Abgottspon, A., Staubli, T., Gloor, N. (2016). Open channel discharge measurement using the acoustic transit time method - a case study, IGHEM Conference, Linz.

Absalon, D., Kubiciel, P., Matysik, M., Ruman, M. (2015). Nowoczesne metody pomiaru przepływu w rzekach. Monografie Komisji Hydrologicznej PTG. 3, 27-43.

Aqua Bielsko-Biała: https://www.aqua.com.pl/

Bares, V., Krajdl, J., Pollert, J. (2008). Open-channel discharge measurement based on ultrasonic doppler velocity profiling - laboratory experiments. 6th International Symposium on Ultrasonic Doppler Methods for Fluid Mechanics and Fluid Engineering, 25-28.

Bugajski, P. (2009). Zmienność ilości dopływających ścieków do oczyszczalni w Tęgoborzy. Infrastruktura i Ekologia Terenów Wiejskich. 9, 23-32.

Bugajski, P., Chmielowski, K., Kaczor, G. (2016). Wpływ wielkości dopływu wód opadowych na skład ścieków surowych w małym systemie kanalizacyjnym. Acta Scientiarum Polonorum, Formatio Circumiectus. 15(2), 3-11.

Główny Urząd Miar: https://www.gum.gov.pl/pl/aktualnosci/2205,Komunikat-dotyczacy-prawnej-kontroli-metrologicznej-przyrzadow-do-pomiaru-przepl.html

GUS: http://stat.gov.pl/
Kaczor, G. (2011). Wpływ wiosennych roztopów śniegu na dopływ wód przypadkowych do oczyszczalni ścieków bytowych. Acta Scientiarum Polonorum, Formatio Circumiectus. 10(2), 27-34.

KAMA Eco-group: http:/www.kama-pomiary.pl/

Lach, S. (2016). Ocena pracy oczyszczalni ścieków w Bielsku-Białej w latach 2008-2012. Badania i rozwój młodych naukowców w Polsce: woda i ścieki. Młodzi Naukowcy, 10, 47-54.

Michalski, A., Sienkiewicz, J., Watral, Z. (2006). Metody pomiaru przepływu na małych otwartych kanałach przepływowych. Diagnostyka, 3(39), 269-278.

Młyński, D., Chmielowski, K., Młyńska, A. (2017). Analiza zmienności ilościowej ściekówdopływających do wybranych oczyszczalnipowiatu sanockiego. Scientiarum Polonorum, Formatio Circumiectus. 16(1), 77-90.

Nivus: https://www.nivus.de/

OMC Envag: https://envag.com.pl

OPWIK: https://opwik.com/

Pawełek, J., Kaczor, G. (2006). Jednostkowe zużycie wody w gospodarstwie domowym w 8-letnim okresie obserwacji. Infrastruktura i Ekologia Terenów Wiejskich. 2/1/, 159-170.

Prawo wodne, Dz. U. 2017 poz. 1566.

SonTek: https://www.sontek.com/

Surfer: https://www.surfer.net.pl/

Teledyne ISCO: http://www.teledyneisco.com/

Teledyne Technologies: http://www.teledyne.com/

Wójcik, K., Wdowikowski, K. (2014). Współczesne metody instrumentalnego pomiaru prędkości przepływu wody w korytach otwartych.Interdyscyplinarne zagadnienia w inżynierii i ochronie środowiska. 4, 978-993.

\section{ANALIZA I OCENA UKŁADU POMIAROWEGO OPARTEGO NA ZWĘŻKACH KAMA DO POMIARU PRZEPŁYWU ŚCIEKÓW W ŚWIETLE WYMAGAŃ PRAWA WODNEGO}

\section{ABSTRAKT}

\section{Cel pracy}

Analiza i ocena działania układów pomiarowych firmy KAMA w odniesieniu do aktualnie stosowanych innych urządzeń i technik pomiarowych używanych do kontroli zrzutu ścieków zgodnie z wymogami nowego PRAWA WODNEGO.

\section{Materiak i metody}

Wykorzystanie danych pomiarowych kontrolowanych układów pomiarowych KAMA R1500 i KAMA 1000 oraz charakterystyk urządzeń pomiarowych innych producentów. 


\section{Wyniki i wnioski}

Przedstawione pomiary kontrolne układów pomiarowych KAMA w kolektorze kołowym oraz w prostokątnym kanale otwartym, jako przykłady najczęściej spotykanych wariantów geometrii punktów zrzutu. Uzyskane dokładności pomiaru natężenia przepływu zwężek KAMA odniesiono do innych, aktualnie stosowanych technik i urządzeń pomiarowych wskazując na najważniejsze przyczyny niższych niż można by się spodziewać dokładności w tym zakresie.

Uświadomienie sobie równoważności stosowanych urządzeń i technik pomiarowych w stałym monitoringu natężenia przepływu zrzucanych ścieków może być pomocne w racjonalnym budowaniu systemu kontrolno-pomiarowego.

Słowa kluczowe: prawo wodne, zrzut ścieków, pomiar natężenia przepływu, urządzenia pomiarowe 